\title{
Computing mobile emissions for the Montreal area
}

\author{
Y. Noriega ${ }^{1}$, M. Florian ${ }^{1} \&$ G. Morneau ${ }^{2}$ \\ ${ }^{l}$ Centre for Research on Transportation, University of Montreal, Canada \\ ${ }^{2}$ Meteorological Service of Canada, Environment Canada, Montreal, \\ Canada
}

\begin{abstract}
A computational procedure, that takes into account climatic data and produces hourly mobile emissions of pollutants on a fine grid for the Montréal Metropolitan area has been developed for the use of Environment Canada. The procedure computes $\mathrm{HC}, \mathrm{CO}, \mathrm{NO}_{\mathrm{x}}, \mathrm{CO}_{2}, \mathrm{SO}_{2}$ and $\mathrm{NH}_{3}$ mobile emissions, as well as 2.5- and $10-\mu \mathrm{m}$ particles. The mobile emissions are calculated on the highways and main arteries of the Montreal road network. The emissions from parked vehicles are computed as well. A user friendly interface, called GRILLE, has been developed for entering parameters and launching the calculations. GRILLE calls up command files for the MOBILE 6.2C software and EMME/2 macros, which include the calculation procedure. This procedure has two parts. The first, obtains emission rates, and the second part, obtains the vehicle flows on the network and estimates the pollution on a fine grid. Results could be retrieved as simple text format or as graphic output. The emission computations can be done for any day and any hour of the year. Use of the model by Environment Canada is described as well.
\end{abstract}

Keywords: mobile emissions, emission rates, network vehicle flows, fine grid.

\section{Introduction}

This paper reports the results of a project entitled, "Calculation of Mobile Emissions on a Fine Grid - Pilot Project in the Montréal Area," that was carried out jointly by the Ministère des Transports du Québec (MTQ), Environment Canada and the Centre de Recherche sur les Transports (CRT) of the Université de Montréal. The aim was to compute, on a very fine scale, the atmospheric 
emissions generated by road transportation in the Montreal area. This project would serve as a pilot for applications to other major urban centres in Canada.

Specifically, the objective of the project was to develop a procedure that would take data entered in meteorological fields on an hourly basis, on which mobile emissions are based, and to provide emissions of the main atmospheric pollutants on a regular grid covering the greater Montréal area, with a resolution of $1 \mathrm{~km}$.

The MTQ maintains the Montreal Area Transportation Model (MOTREM), a transportation planning model, by using the EMME/2 software. The procedure had to calculate emissions using the MOBILE6.2C software (the Canadian version of MOBILE6.2) and the vehicle flows computed by EMME/2.

The model developed meets these expectations and does so efficiently.

\section{The proposed model}

This section provides a summary of the various elements of the model. For a complete description of the model see CRT [1].

\subsection{Basic characteristics}

The pollutants and emissions to be evaluated are listed in Table 1.

Emissions are calculated on an hourly basis for the 28 types of vehicles in MOBILE6.2C (for more details on MOBILE6.2 see USEPA [4]), with evaluations for one or 14 speeds on freeways and main arteries, as specified in the same table.

The model calculate $\mathrm{HC}, \mathrm{CO}, \mathrm{NO}_{\mathrm{x}}, \mathrm{CO}_{2}, \mathrm{SO}_{2}$ and $\mathrm{NH}_{3}$ pollutant emissions, as well as 2.5 and $10 \mu \mathrm{m}$ Particulate Matters : $\mathrm{SO}_{4}$, Organic Carbon of Diesel (OCARBON), Elemental Carbon of Diesel (ECARBON), Total Carbon of Gasoline (GASPM), BRAKEWEAR, TIREWEAR and TOTAL.

Except for BRAKEWEAR and TIREWEAR, these are exhaust emissions. For $\mathrm{HC}, \mathrm{CO}$ and $\mathrm{NO}_{\mathrm{x}}$, exhaust emissions on start up are also calculated. The model also determines HC evaporative emissions: Hotsoak, Diurnal, Resting, Running Loss and Crankcase. Some of these emissions are produced when vehicles are parked.

Emission rates by MOBILE6.2C vehicle types are aggregated into the four types of MOTREM vehicles considered: Autos, Regular Trucks, Heavy Trucks and Buses. The eight MOTREM road types are classified on freeways and arterial roads.

Emission rate/speed functions generated from evaluations for 14 speeds by MOBILE6.2C are used to determine by interpolation emissions for all the speeds that are computed by the transportation model on the road network.

\subsection{Benefits}

The developed procedures have the following benefits. 
Table 1: $\quad$ Emissions estimated using MOBILE6.2C.

\begin{tabular}{|c|c|c|c|c|c|}
\hline POLLUTANT & EMISSION & & VEHICLE & ROAD & SPEEDS \\
\hline \multirow{7}{*}{$\mathrm{HC}$ (VOC) } & RUNNING & & ALL VEHICLES & $\begin{array}{l}\text { FREEWAY and } \\
\text { ARTERIAL } 1\end{array}$ & 14 \\
\hline & \begin{tabular}{|l} 
START \\
\end{tabular} & & $L D+M C$ & ALL ROAD 2 & $1 *$ \\
\hline & HOTSOAK & & $G+M C$ & ALL ROAD & 1 \\
\hline & \begin{tabular}{|l|} 
DIURNAL \\
\end{tabular} & & $G+M C$ & ALL ROAD & 1 \\
\hline & RESTING & & $G+M C$ & ALL ROAD & 1 \\
\hline & RUNLOSS & & $G-M C$ & $\begin{array}{l}\text { FREEWAY and } \\
\text { ARTERIAL }\end{array}$ & 14 \\
\hline & CRANKCASE & & $G+M C$ & ALL ROAD & 1 \\
\hline \multirow[t]{2}{*}{$\mathrm{CO}$} & RUNNING & & ALL VEHICLES & \begin{tabular}{|l|} 
FREEWAY and \\
ARTERIAL
\end{tabular} & 14 \\
\hline & START & & $L D+M C$ & ALL ROAD & 1 \\
\hline \multirow[t]{2}{*}{$\mathrm{NO}_{x}$} & RUNNING & & ALL VEHICLES & $\begin{array}{l}\text { FREEWAY and } \\
\text { ARTERIAL }\end{array}$ & 14 \\
\hline & \begin{tabular}{|l} 
START \\
\end{tabular} & & $L D+M C$ & ALL ROAD & 1 \\
\hline $\mathrm{CO}_{2}$ & RUNNING & & ALL VEHICLES & $\begin{array}{l}\text { FREEWAY or } \\
\text { ARTERIAL } 3\end{array}$ & 1 \\
\hline $\mathrm{SO}_{2}$ & RUNNING & & ALL VEHICLES & $\begin{array}{l}\text { FREEWAY or } \\
\text { ARTERIAL }\end{array}$ & 14 \\
\hline \multirow[t]{2}{*}{$\mathrm{NH}_{3}$} & RUNNING & & ALL VEHICLES & $\begin{array}{l}\text { FREEWAY or } \\
\text { ARTERIAL }\end{array}$ & 1 \\
\hline & & PM & & & \\
\hline $\mathrm{SO}_{4}$ & RUNNING & $\begin{array}{c}2.5 \\
10\end{array}$ & ALL VEHICLES & $\begin{array}{l}\text { FREEWAY or } \\
\text { ARTERIAL }\end{array}$ & 14 \\
\hline OCARBON & RUNNING & $\begin{array}{c}2.5 \\
10\end{array}$ & ALL VEHICLES & $\begin{array}{l}\text { FREEWAY or } \\
\text { ARTERIAL }\end{array}$ & 1 \\
\hline ECARBON & RUNNING & $\begin{array}{c}2.5 \\
10\end{array}$ & ALL VEHICLES & $\begin{array}{l}\text { FREEWAY or } \\
\text { ARTERIAL }\end{array}$ & 1 \\
\hline GASPM & RUNNING & $\begin{array}{c}2.5 \\
10\end{array}$ & ALL VEHICLES & $\begin{array}{l}\text { FREEWAY or } \\
\text { ARTERIAL }\end{array}$ & 1 \\
\hline LEAD & RUNNING & $\begin{array}{c}2.5 \\
10\end{array}$ & ALL VEHICLES & $\begin{array}{l}\text { FREEWAY or } \\
\text { ARTERIAL }\end{array}$ & 1 \\
\hline BRAKE WEAR & BRAKE WEAR & $\begin{array}{c}2.5 \\
10\end{array}$ & 1 VEHICLE & ALL ROAD & 1 \\
\hline TIRE WEAR & TIRE WEAR & $\begin{array}{c}2.5 \\
10\end{array}$ & ALL VEHICLES & ALL ROAD & 1 \\
\hline \multicolumn{6}{|c|}{$\begin{array}{ll}1 & \text { FREEWAY and ARTERIAL. The rates are different. }\end{array}$} \\
\hline \multicolumn{6}{|c|}{2 ALLROAD. MOBILE62 uses a single rate. } \\
\hline \multicolumn{6}{|l|}{3 FREEWAY C } \\
\hline
\end{tabular}

\subsubsection{User-friendly data-entry interface}

The model uses a user-friendly interface called GRILLE for the entry of input parameters and to launch executions. It was developed in Java in a Windows environment. Input parameters in GRILLE are organized into five groups: date and time of the evaluation, external conditions, fuel characteristics, advanced options and cells on the grid. Figure 1 shows GRILLE's main window. 


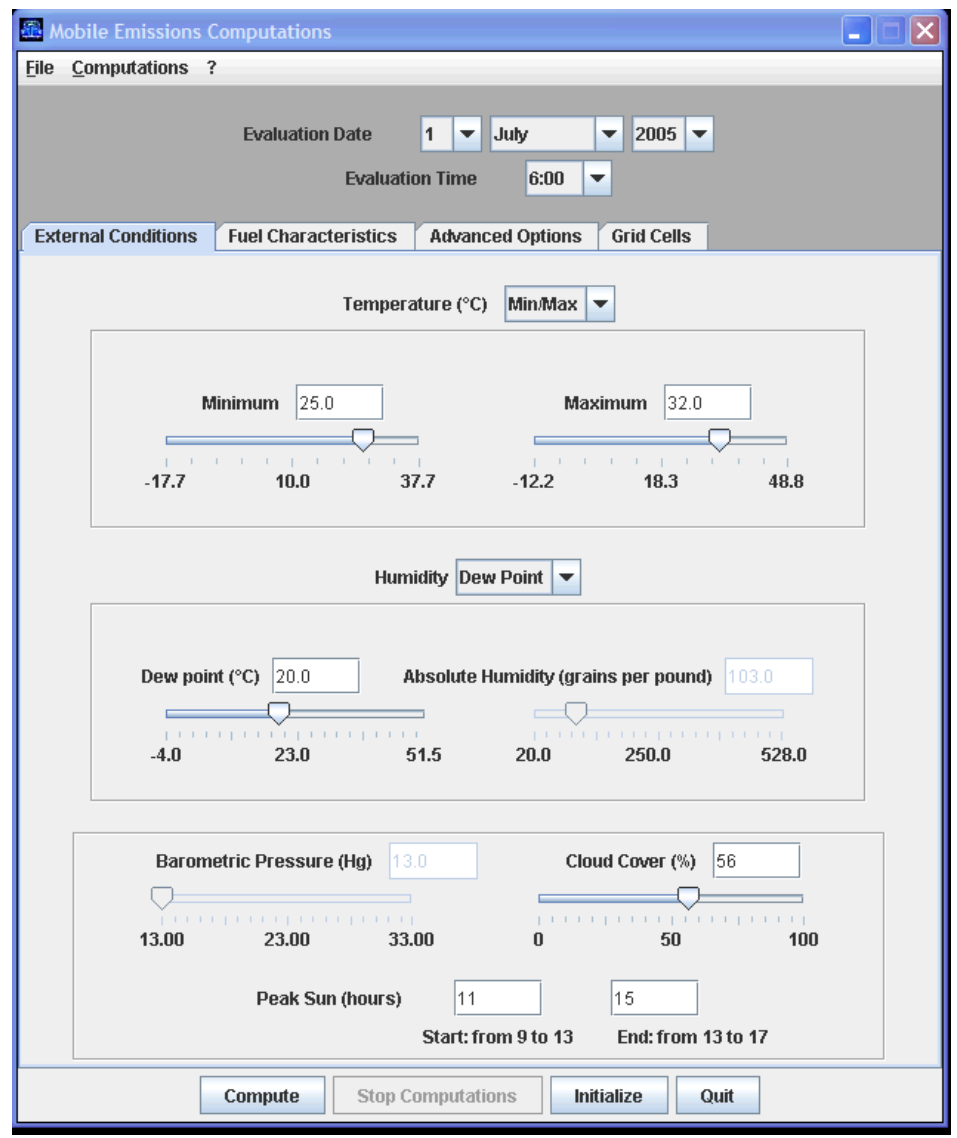

Figure 1: GRILLE's window.

The date and time of the evaluation are crucial parameters. They allow identifying other input parameters in the model in a manner that is transparent for the user.

External conditions include the meteorological data needed for MOBILE6.2C to estimate emissions. These conditions are temperature, humidity, barometric pressure, cloud cover, peak sun and sunrise/sunset hours. These are the data that the user is most interested in manipulating to determine the pollution emitted under various weather conditions.

Fuel characteristics refer to the level of sulfur in the fuel and the Reid Vapour Pressure (RVP) factor. The default values allowed by Environment Canada are saved in a file and accessed directly by GRILLE.

The advanced options allow two elements, which are not integrated in the computations to be evaluated: government programs and oxygenated fuel.

Finally, the cells of the grid can be defined by the user in terms of size (width and height) and location (horizontal and vertical offsets). 


\subsubsection{Efficiency in the use of related software}

MOBILE6.2C can be used to generate emission estimates separately by average speed, roadway type and vehicle class. These disaggregated values can be postprocessed for various aggregations of the emissions estimates that are required.

The model uses the ability of MOBILE6.2C to calculate, in a single step, all types of emissions for all pollutants and all types of vehicles, for one type of road and one size of particulate, for one speed (the particulate estimation is independent of the estimation of other pollutants). The number of executions in MOBILE6.2C in an hourly evaluation is reduced to two cases: Freeway with $10 \mu \mathrm{m}$ Particulates and Arterial with $2.5 \mu \mathrm{m}$ Particulates. Two evaluations are also required for months other than January or July (the only choices of MOBILE6.2C).

\subsubsection{Possibility of estimating pollution for any time of day, week, Saturday or Sunday, and any month of the year}

The travel information provided by MTQ corresponds to the five MOTREM periods of the day (am peak, mid-day off-peak, pm peak, evening off-peak and night) for a typical fall week. The scope of this project is to estimate road traffic on an hourly basis for weekdays and weekends and for all months of the year.

An analysis of the road counts (obtained from the MTQ's CIR-6002 system database) provides the information needed to determine travel distribution patterns throughout the year, the week and the day.

Given that travel patterns are different for each type of vehicle, the analysis deals only with data disaggregated by type of vehicle.

Vehicle by period flows for a typical fall day are adjusted by these distributions patterns in order to reflect hourly traffic conditions on a weekday, Saturday or Sunday and for any month of the year.

\subsection{Limitations}

The inputs for MOBILE6.2C lack of information developed specifically for the Montréal area. We must repeatedly use default U. S. values.

Other MOBILE6.2C limitations, such as the admissible range of temperatures (from -17.7 to $48.8^{\circ}$ Celsius) do not allow the model to be fully adapted to the conditions of the Montréal area. The lowest temperatures in the Montreal area are of the order of $-30^{\circ}$ Celsius.

When aggregating emissions from various types of vehicles into a single vehicle, due to a lack of data, we must suppose that all vehicles travel the same number of kilometres per year.

The results obtained for emissions calculated at centroids for Saturdays and Sundays should be used with care because they are obtained using traffic distribution factors and not with information regarding personal travel. The same reservation applies to holiday periods.

\section{General computation procedure}

The general computation procedure consists of two main parts, "Obtaining emission rates" and "Obtaining network flows and estimating pollution on a fine 
grid." Figures 2 and 3 show the steps taken in the calculation procedure, including input and output elements.

\subsection{Obtaining emission rates}

The purpose of this part is to create input files for the MOBILE6.2C software, extract emission rates from the same software's output files and incorporate the rates into the functions to be used by EMME/2 in the second part of the procedure (for details on EMME/2 see INRO [3]).

"Obtaining the emissions rates" begins when the user requests an execution in the GRILLE interface. First, the data the user provides to GRILLE is saved to a file and then integrated into the MOBILE6.2C input files. Several input files are created in this way due to the range of emissions to be calculated. MOBILE6.2C is launched.

The MOBILE6.2C output file containing the desired results depends on the emission to be retrieved. Running, Running loss, Crankcase and Particulate Matters emissions rates (required in grams $/ \mathrm{km}$ ) are obtained directly from the descriptive output files, while Start and Hot soak, Resting and Diurnal emissions rates (required in grams/vehicle or grams/hour) are obtained in a disaggregated manner and must be calculated in a data processing environment.

Once the emission rates are retrieved for each of the 28 types of vehicles, they are aggregated by the four MOTREM types. In the event that two evaluations are required (when the evaluation month is different of January and July), the results for the two months are combined in order to obtain emission rates for the desired month.

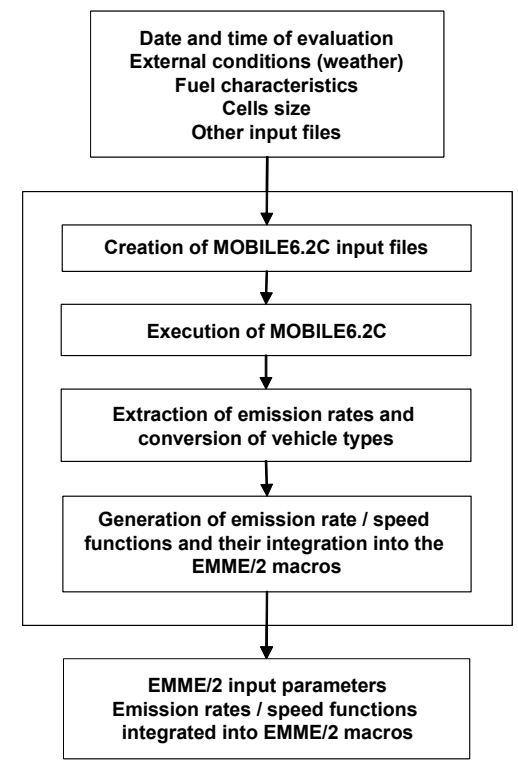

Figure 2: Obtaining emission rates, flow diagram. 


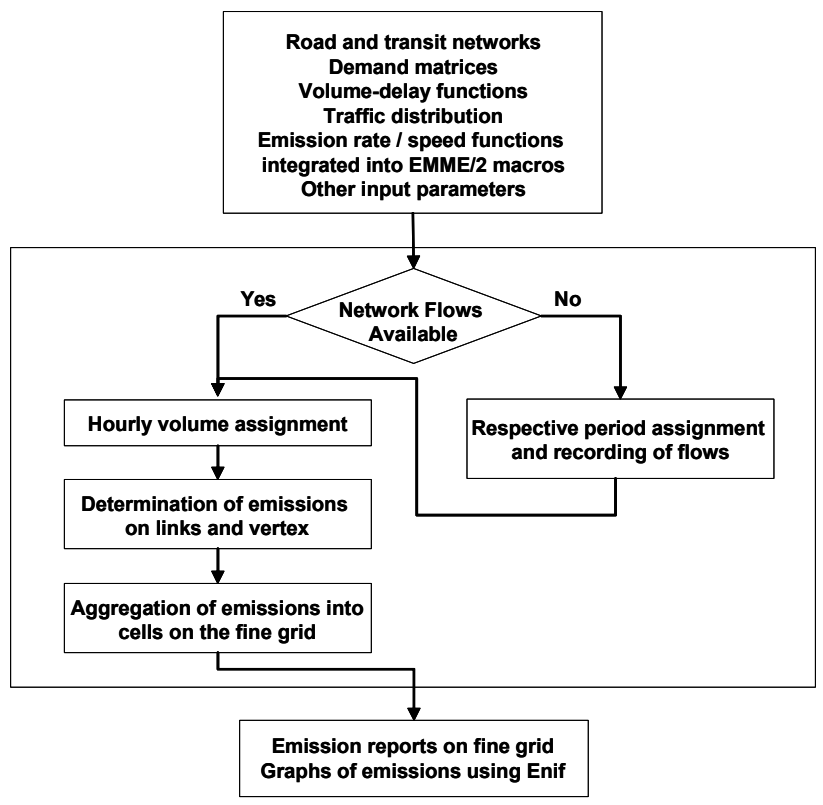

Figure 3: Obtaining network flows and estimating pollution on a fine grid, flow diagram.

Depending on the type of emission, the rate may be a constant or based on speed. In both cases, the rates are converted to mathematical expressions in an EMME/2 macro procedure for later use. For emissions for which rates vary by the type of road, two functions are generated.

\subsection{Obtaining network flows and estimating pollution on a fine grid}

The purpose of this part is to determine the flow of vehicles on the road network, associate previously calculated emissions rates with that flow and quantify existing pollution in the cells of a fine grid. This part is performed by using the EMME/2 software and the MOTREM data bank.

In "Obtain network flows and estimating pollution on a fine grid" one of two routines will be launched.

\subsubsection{Flows not available}

If vehicle flows are not available for the year, season (summer or other), day (weekday, Saturday or Sunday) and desired MOTREM period (period associated with the evaluation hour), vehicles are assigned by period. The year, season, day and period of the day are needed to choose the demand, auto network and transit network to be used in the assignment.

The period assignment process, as set forth below, is based on the one used by the MTQ. 
1. Initialization, Buses as fixed volume on links

2. Auto assignment in a single class

3. Heavy Truck assignment with generalised costs. Travel time is the average of the all-or-nothing time and the Auto travel time.

4. Update of fixed volumes to include Heavy Truck volumes

5. Multi-class Auto - Regular Truck assignment

Vehicle flows and aggregated demand at origins and destinations are stored for later use.

\subsubsection{Flows available}

If the flows are already available, period to hour factors are applied to them and to the demand. Flows for all types of vehicles are merged as a fixed flow on links. Then a no demand, all-or-nothing hourly assignment is performed.

The speed of vehicles is calculated on links. Then emissions rates are associated with vehicles moving at different speeds, and pollution is determined at links and centroids.

Finally, the GRTOOL program is launched. For each link (and centroid) pollutant it splits the pollution according to the overlap with different grid cells. Then GRTOOL accumulates the pollution for each cell on the grid. These results are saved in the final results files.

\section{Preliminary results}

Figures 4 and 5, obtained using the graphical interface Enif, show the emissions of $\mathrm{HC}(\mathrm{VOC})$ on a fine grid for the Montréal area.

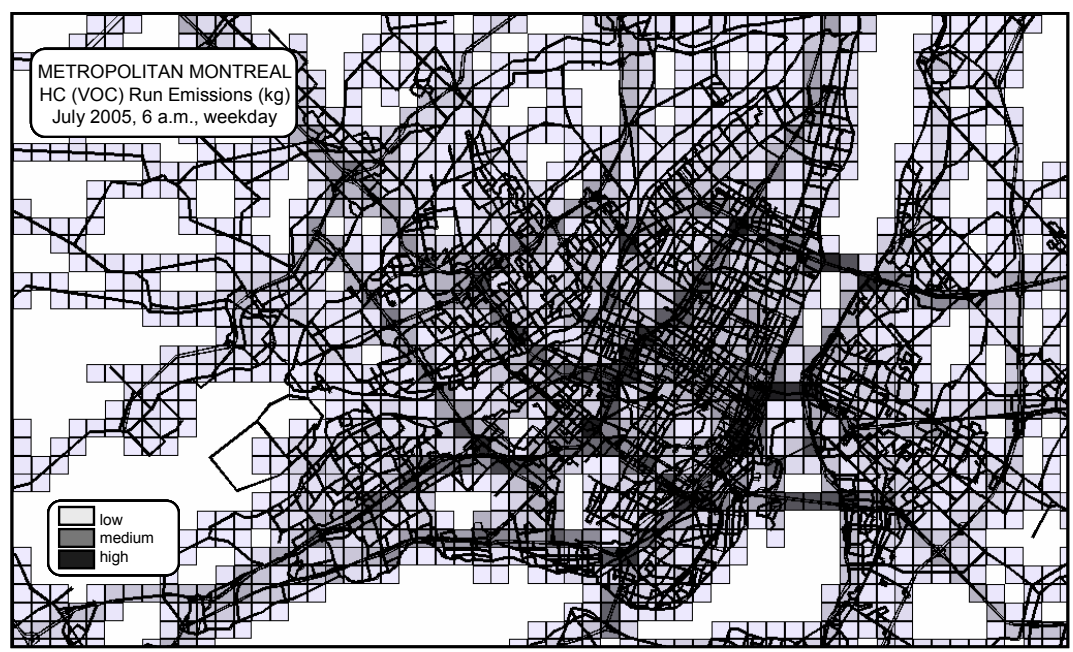

Figure 4: $\quad$ HC (VOC) run emissions ( $\mathrm{kg})$. 


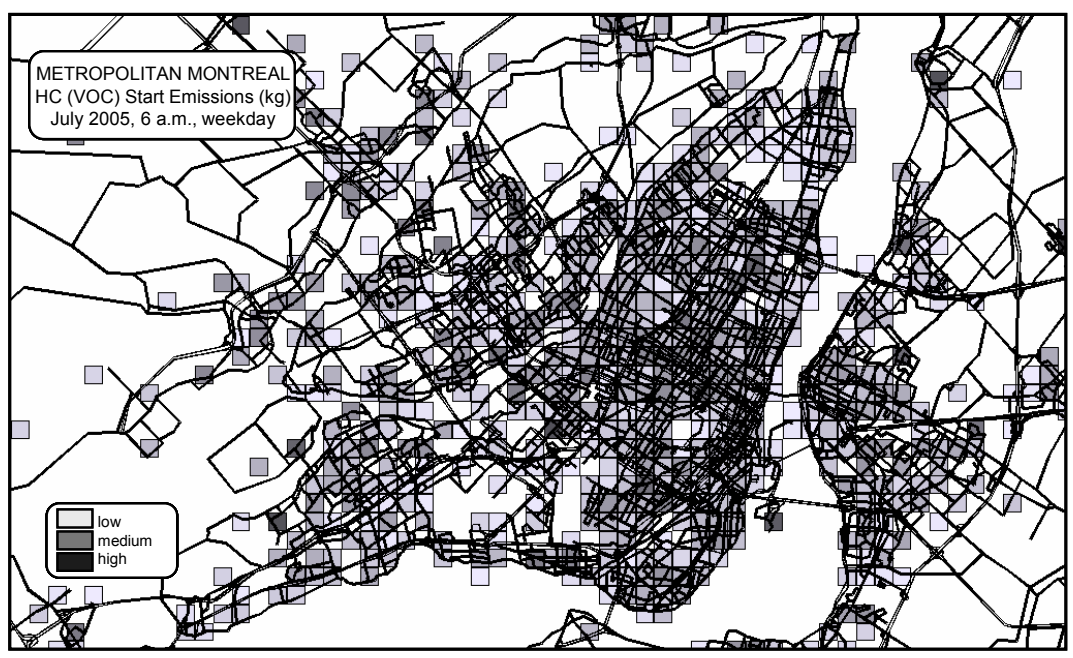

Figure 5: $\quad \mathrm{HC}(\mathrm{VOC})$ start emissions (kg).

\section{Simulation of a smog episode with GRILLE}

The Meteorological Service of Canada evaluated GRILLE during a regional smog episode of 2001 in the Montreal area. The simulated episode started on 30 July and ended on 5th August 2001, with 2nd August being a day where southern Quebec experienced a regional smog episode, the 8-hour running average of ozone concentrations exceeding the $65 \mathrm{ppb}$ threshold of the Canada-wide Standard at several monitoring locations.

Quebec experienced a regional smog episode, the 8-hour running average of ozone concentrations exceeding the $65 \mathrm{ppb}$ threshold of the Canada-wide Standard at several monitoring locations.

The air quality model used in this study was the Canadian AURAMS model, Gong et al [2]. AURAMS is mainly used to simulate smog (ozone and $\mathrm{PM}_{2.5}$ ) and dry and wet deposition (acid rain). The AURAMS air quality model is integrated twice on a domain covering North-eastern North America. The first run uses the regular SMOKE (Sparse Matrix Operator Kernel Emissions; available from the US EPA) on-road vehicle emissions based on the 2000 Canadian inventory. This input file was then modified for the second run; the emissions generated by GRILLE were aggregated on the $21-\mathrm{km}$ model grid and replaced the SMOKE-generated data over the Greater Montreal region.

The daily maximum ozone concentrations predicted by the AURAMS model on 2nd August 2001 from the two scenarios differs as would be expected. The ozone concentrations increase from 3 to $5 \mathrm{ppb}$ downwind of Montreal in a narrow plume. This is due to the fact that the GRILLE emissions are better distributed spatially with a more pronounced and sharper peak over Montreal itself and reduced emissions in the suburbs. These reduced emissions in the periphery lead to a decrease in ozone on each side of the central plume. A second 
factor responsible for the difference is the change in the emission rates, the decrease in NOx emissions expected to lead to an overall reduction in ozone concentrations.

The reported daily maximum ozone concentrations from 11 monitors in Southern Quebec were compared to the AURAMS values for the two emission scenarios. Common statistics between the model and observations are shown on table 2. It shows that the use of GRILLE to compute the on-road vehicle emissions has significant benefits for ozone prediction near Montreal and downwind. It reduces the bias and gives better correlation, the root mean square error is reduced and the variability of the model is closer to the observations.

Table 2: Model statistics for the prediction of the daily maximum ozone concentration (66 model-observation pairs).

\begin{tabular}{|l|c|c|}
\hline & GRILLE & SMOKE \\
\hline Bias (ppb) & -1.68 & -3.09 \\
\hline Correlation coefficient & 0.36 & 0.24 \\
\hline Normalized standard deviation & 0.66 & 0.58 \\
\hline Centered root mean square error $(\mathrm{ppb})$ & 18.9 & 19.8 \\
\hline
\end{tabular}

\section{References}

[1] Centre of Research on Transportation, Calculation of Mobile Emissions on a Fine Grid. Final Report. University of Montreal, 2005.

[2] Gong, W. Dastoor, A. P., Bouchet, V. S., Gong, S., Makar, P. A., Moran, M. D., Pabla, B., Ménard, S., Crevier, L. P., Cousineau, S. and Venkatesh, S., Cloud processing of gases and aerosols in a regional air quality model (AURAMS). Atmospheric Research, 82 (1-2), 2006.

[3] INRO Consultants Inc., EMME/2 User's Manual. Release 9.6, Montreal, 2005.

[4] United States Environmental Protection Agency. User's Guide to MOBILE6.1 and MOBILE6.2: Mobile Source Emission Factor Model, USA, 2002. 